\title{
A fuzzy synthetic evaluation of the challenges of smart city development in developing countries
}

\begin{abstract}
Purpose: This study presents a fuzzy synthetic evaluation of the challenges of smart city realisation in developing countries, using Nigeria as a case study. By defined and delineating the problems facing the country, more viable directions to attaining smart city development can be achieved.
\end{abstract}

Design/Methodology/ Approach: The study adopted a post-positivist philosophical stance with a deductive approach. A structured questionnaire was used to gather data from built environment professionals involved in the delivery of Nigerian public infrastructures. Six dimensions of the challenges of smart cities were identified from literature and explored. These are governance, economic, social, technological, environmental, and legal issues. Data gathered were analysed using Cronbach alpha test for reliability, Shapiro-Wilks test for normality, Kruskal-Wallis H-Test for consistency, and Fuzzy synthetic evaluation test for the synthetic evaluation of the challenges of smart city attainment.

Findings: The findings revealed that all six assessed dimensions have a significant impact on the attainment of smart cities in Nigeria. More specifically, issues relating to environmental, technological, social and legal challenges are more prominent.

Originality/Value: The fuzzy synthetic approach adopted provides a clear, practical insight on the issues that need to be addressed before the smart city development can be attained within developing countries.

Keywords: Smart city development, Industry 4.0, information technology, smart technology, urban development, construction industry

\section{INTRODUCTION}

Past studies have noted that a city is a highly organised community which is a pillar of every nation's economy and its sustainability (Bawa et al., 2019; Komolafe et al., 2019). Unfortunately, in most developing countries, particularly in Africa, most cities have fallen short of the description of a city. A common culprit of this problem is the rapid urbanisation being experienced in most African cities in recent time. It is projected that by the year 2050 , over half of Africa's population will be living in cities (United Nations, 2017). Ogundare and 
Ogunbodede (2014) noted that in the case of Nigeria, there is a high rate of urbanisation with more people concentrating in cities, due to the city's ability to create settlement change and development (also cf. Biswas, 2019). This habitually puts severe pressure on the meagre available resources within these cities, with too many people depending on scant infrastructure provisions. The resultant effect of this is inadequate and deteriorated infrastructures, poor living conditions and an unhealthy environment. Therefore, considering the important nature of cities to socio-economic development and the continuous growth in population and rapid urbanisation being experienced in most countries, the call for cities to be 'smart' has become crucial.

Attempts to explicitly define a smart city have proven problematic. However, SikoraFernandez (2018) has noted that there are certain descriptions in the body of knowledge that can give pointers to a city that is smart. Silva et al. (2018) described a smart city as a connected city for humans and cyberspace. From a more comprehensive dimension, smart city is seen as the improvement of economic and political efficiency, as well as the development of a social and cultural aspect of cities through networked infrastructures (Clarke et al., 2019; Hollands, 2008). Following this insight on the description of a smart city, it can be deduced that its sole purpose is to better the standard of living of humans. However, no matter how laudable the proposed strategies for achieving smart cities within a country are, and the intent behind them, they are worthless if they are not contextualised within the community they are designed for. It is only by critically evaluating the problems within a city and solving them that the implementation of smart ideas and the realisation of smart cities can be achieved. Furthermore, the saying that "no two cities are alike" (Cowen, 2017) further buttresses the need to contextualised smart ideas as the 'one size fits all' approach proposed for the attainment of smart cities can no longer be considered as reasonable (Alizadeh, 2017). Cities vary in sizes and their associated problems. Expecting all cities to align their strategy for achieving smart city given existing complex policy agenda already in place, might leave the attainment of smart cities in some countries, a dream than a reality (Angelidou, 2014; Nam and Pardo, 2011). This knowledge has seen studies now placing emphases on the need to understand the local contexts that may influence the attainment of a smart city (Alizadeh 2017; Neirotti et al., 2014; Sepasgozar et al., 2019).

It is based on this knowledge that this paper seeks first to determine and then assess the challenges faced by governments within developing countries (using Nigeria as a case study) 
as they move towards embracing smart city developments. This is done with a view to guiding government and policymakers in their quest to deliver a better-quality life for their citizens through improved policies.

\section{CHALLENGES OF SMART CITY DEVELOPMENT}

Rana et al. (2019) assessed the barriers of smart cities in India and concluded based on existing literature that the barriers towards smart city attainment can be categorised into six distinct groups. These are, i) economic, ii) social, iii) technology, iv) governance, v) environmental, and vi) legal and ethical barriers. This classification was based on the modification of the PESTLE analysis, wherein the political element was modified to governance, and the ethical aspect was added to the legal dimension. These six dimensions were adopted in this current study while the variables under each dimension were carefully sourced from other relevant literature vis-à-vis their applicability to the study area.

Issues surrounding governance are the bane of smart city development in most countries (Rana et al., 2019). Nam and Pardo (2011) posited that it is practically impossible to have an all-inclusive smart city in an environment wherein cooperation between city's network such as public institutions, private sector, voluntary sector and citizens is absent. Similarly, instability in government is a hindrance to smart city attainment in the case of cities in the South and East of the Mediterranean (Monzon, 2015). When governance is poor, and trust does not exist between the government and its citizen, smart city development cannot be attained (Ruhlandt, 2018). For instance, in 2016, the Lagos State Governor signed a smart city deal with Dubai with the sole aim of transforming Lagos - one of the major commercial cities in Nigeria- into a smart city. Unfortunately, the realisation of this deal is yet to occur (Ekwealor, 2016). Likewise, in June 2017, the Nigerian government announced the 'Nigerian Smart City Initiative' which was aimed at increasing ICT usage in physical infrastructure and service delivery. The initiative has also failed to bear fruit in major cities of the country. These scenarios are bound to create significant doubt in the mind of the citizens and distrust in the government.

Economic instability is also a vital issue. Studies have shown that the resultant effect of instability and uncertainty in any economy is severe on long-term growth, cost of living and infrastructure delivery (Adefeso and Mobolaji, 2010; Akanni and Osinowo, 2013). Unfortunately, Nigeria is confronted with these issues because of its historical economic 
instability (Abioye 2017; Aghimien et al., 2018). Bello-Schünemann and Porter (2017) noted that economic growth in Nigeria is influenced by substantive deficit in the country's basic physical infrastructure.

Kummitha and Crutzen (2019) and Nam and Pardo (2011) noted the issue of lack of citizens participation as a problem facing smart cities. Datta (2015) emphasised that in most developing countries, lack of a supportive environment can deter the actualisation of smart cities. Monzon (2015) noted that in Europe and South and East Mediterranean, most countries are faced with social issues such as unemployment, lack of social cohesion, poverty and inequality and poor education which deters their attainment of smart cities. The situation is similar in Nigeria as persistent poverty is a common issue (Danaan, 2018). The Vanguard (2018) reported that the country has the highest number of people living in extreme poverty when compared to other countries around the world. According to George and Ukpong (2013), the major culprits of this high level of poverty are unemployment, high level of dependent population, and overpopulation. Giffinger et al. (2007) noted that one of the essential dimensions needed for smart city attainment is having smart people derived from a proper education. A poor education engenders a poor awareness of the concept of smart cities which is another crucial challenge of attaining smart cities (cf. Kogan and Lee, 2014; Rana et al., 2019).

Since the advent of industry 4.0 at the 2011 Hannover fair in Germany (Newman et al., 2020), many developed and developing countries have been embracing the different industry 4.0 related technologies in different sectors of their economy (Crnjac et al., 2017). Internet of Things, big data analytics, automation and robotics, sensors, drones, cloud-based manufacturing, digitalisation of services are all becoming common technological features adopted to improve service delivery in some of these countries (Aghimien et al., 2019; AlNuaimi et al. 2015; Erol et al., 2016; Ghosh et al., 2020). Furthermore, the introduction of the fifth-generation $(5 \mathrm{G})$ wireless communication (which promises the effective spread of smart city concepts (Marabissi et al., 2019)) has been embraced in most countries in Europe and the United States of America (Loghin et al., 2020). However, the case is not the same for most African countries where lack of adoption and poor development is still evident (Aghimien et al., 2019). This lack of adoption affects the attainment of smart cities in these countries (Bibri, 2019). For instance, Al-Nuaimi et al. (2015) noted a significant influence of big data analytics on the attainment of smart cities. However, its proper adoption is mostly 
hindered by factors such as privacy and security of data (Pärn and Edwards, 2019). Bawa et al. (2016), and Rana et al. (2019) also added that virus threats and lack of privacy are important issues of technology adoption. Another critical issue is the high cost, lack of access, and slow internet connectivity that has bedevilled most Africa countries. Akamai - a global content delivery platform - ranked the internet speed of Nigeria at 114 out of 143 countries surveyed in May 2017 (Adepetun, 2017).

Similarly, people within an environment have an important role to play in the proper deployment of smart applications (Al-Nuaimi et al., 2015; Kramers et al., 2014). An increase in population generates a concomitant increase of data, which if not properly managed, can serve as a drawback for the attainment of smart cities. Also, population increase generate traffic congestion, pollution and increased social inequality (Monzon, 2015; Neirotti et al., 2014). Neirotti et al. (2014) and Rana et al. (2019) have earlier noted that lack of sustainability consideration (such as proper waste management) can generate poor living conditions for city's citizens. Furthermore, legal issues are crucial, especially since big data collection is involved in the smart city concepts. Khan et al. (2014) noted that there is a fine line between gathering citizens' data and ensuring privacy rights are protected. Based on the above issues, Table 1 reproduced the challenges to smart city development.

<Insert Table 1 about here>

\section{RESEARCH METHOD}

The study adopts a post-positivism philosophical stance (Roberts et al., 2018; Al-Saeed et al., 2020), using a deductive approach (cf. Edwards et al., 2019; Edwards et al., 2020) since the study sought to identify and assess the challenges of smart city development. A survey strategy of enquiry was conducted using a structured questionnaire. A questionnaire survey was used because of the need to solicit a response from respondents across the country vis-àvis selecting a state or region to represent the entire country. Tan (2011) described the questionnaire survey as a simple survey approach which can cover a broader range of audience within a short period of time. Blaxter et al. (2001) further affirmed that the questionnaire is among the most widely used social research techniques, hence its adoption. 
Two sections were used in the questionnaire to harness information from respondents. Section one gathered information on the respondent's background, while section two harnessed information on the study's objective. A closed-ended questionnaire design was adopted. The respondents were provided with 34 variables and were asked to rate them based on their level of significance using a 5-point Likert scale, with five being very high and one being very low. Chan et al., (2017), and Wong et al., (2016) adopted a similar approach in their studies on the strategies for promoting green building, and green building procurement.

The study sought responses from built environment professionals with a minimum of five years of working experience in the construction industry in the country's six regions, viz: South-West (SW), South-South (SS), North-Central (NC), North-West (NW), South-East (SE) and North-East (NE). These built environment professionals were selected on the premise that they are primarily involved in the planning, design, delivery and management of cities and their development. Since the study cut across the entire country, an electronic questionnaire was adopted for easy sending and collection of feedback. Details of some respondents were obtained from a professional database, and they were sampled conveniently based on their willingness to participate. To further increase responses, a snowball approach was also adopted. Heckathorn (2011) described the snowball sampling as a technique that assumes that a link exists between the initial sample and others within the same targeted population. This allows a series of referrals to be made within a circle of acquaintance. Atkinson and Flint (2001) have earlier stated that the snowball approach is beneficial when there is a need to increase the sample size - and as an indication of this, Chan et al. (2017) and Rahman (2014) adopted a similar approach to their study. Based on the approach adopted, determining the exact number of distributions becomes difficult, thus making the calculation of a total response rate impossible. However, a total of 154 responses were collected after one month and three weeks of questionnaire administration.

Data analysis includes first testing the reliability of the questionnaire using Cronbach's alpha test. An overall alpha value of 0.782 was derived for all the assessed variables, thus indicating that the instrument is reliable as suggested by Moser and Kalton (1999). Data normality was assessed using the Shapiro-Wilk test, which according to Ghasemi and Zahediasi (2012), is suitable for assessing the normality of data gathered from a sample size of less than 2,000 as in the case of this study. Shapiro-Wilk test revealed that the $p$-value of all the 34 assessed challenges is 0.000 , which is $<0.05$ required criteria for normality. This 
means that the data gathered is not normally distributed, hence only statistical methods that do not require a data to normally distributed approach can be adopted. Furthermore, since the respondents were sampled from different regions, there is the possibility of some disparity in the way they ranked the assessed challenges. This assumption necessitated the need to identify the specific factors with a significant disagreement between respondents from the six different regions. Consequently, the Kruskal-Wallis H-Test, which is a non-parametric test used in ascertaining the significant difference in the view of three or more group of respondents was adopted. This test revealed that 32 variables out of the 34 assessed had a $p$ value $>0.05$. This implies that there is no statistically significant difference in the view of the professionals from the six different regions of the country with respect to these 32 variables. Further to this, the impact of the identified challenges of smart city attainment was analysed using the fuzzy set theory via the fuzzy synthetic evaluation (FSE).

Fuzzy set theory has the capability to solve issues surrounding ambiguity, subjectivity and poor precision in the judgement of problems (Pedrycz et al., 2011; Zhao et al., 2013) as in the case of the identification of challenges of new developments such as smart city attainment. Unlike the other second-generation multivariate analysis, fuzzy set theory can, in a precise and objective manner, explain and quantify information that is not correctly defined. This is achievable since the fuzzy set theory adopts linguistic variables and terms to create the distinctive imprecision in the human cognitive process (Wuni et al., 2020). Ma and Kremer (2015), Xia et al. (2011), and Zimmermann (2001) all reiterated that with the fuzzy set theory mathematical operators can be applied to the fuzzy domain, and linguistic facet of available data can be quantified. Preferences for individual or group decision-making can also be achieved. FSE, which is an application of the fuzzy set theory (Zhao et al., 2016) was adopted for this current study. Xu et al. (2010) describe FSE as an approach that helps assess multiple criteria decision-making. The application of FSE for this study was premised on the need to determine the synthetic evaluation of the challenges of smart cities development in Nigeria in a fuzzy decision environment with multiple criteria (cf. Mu et al., 2014). Moreover, this analysis approach has been adopted in different built environment researches to solve complex issues (Ameyaw and Chan, 2015; Wuni et al., 2020;).

\section{RESULTS AND DISCUSSION}

\section{Background information of respondents}


The demographic profiles of respondents revealed that more responses were obtained from the SW with a $27.9 \%$ response rate; this is followed by NC with $20.1 \%$ and SS with $18.8 \%$. Reasons for this can be attributed to the fact that the Lagos state (the country's commercial city with a significant number of construction companies and professionals) is located in the SW. The Federal Capital Territory (Abuja) which is the country's administrative city (with a considerable number of construction projects being executed) and is in the NC (Aghimien et al., 2018). The least represented regions in the study are SE, NW and NE with $11.7 \%, 11.7 \%$ and $9.7 \%$ respectively. More Engineers and Quantity Surveyors participated in the study with $21.4 \%$ and 23.45 respectively. This was followed by Builders (17.5\%) and Architects (11.7\%). The least represented professionals were Town planners, Land Surveyors, Estate Valuers and Project managers. Most of these respondents work within contracting (41.6\%) and consulting $(31.8 \%)$ organisations. The least was the government entity with $26.6 \%$. Most of these respondents (40.9\%) possess a bachelor's degree. This is followed by post-graduate diploma (18.8\%), master's degree (16.2\%) and Higher national diploma (15.6\%). The least qualifications are ordinary national diploma and doctorate with $5.8 \%$ and $2.6 \%$ respectively. The average years of working experience of the respondents were calculated as 9.3 years. Overall, background information revealed that significant response was received from the country's different regions, and key professionals working within the built environment were represented. Also, these respondents have significant academic qualifications to understand the questions posed and they equally have a considerable amount of experience to give reliable responses needed for data analysis.

\section{Fuzzy synthetic evaluation of the challenges of smart city development}

In using FSE, first, the evaluation of the different challenges is undertaken at the third level, while the criticality of the dimensions (wherein these challenges are grouped) is determined at the second level. The first level then gives the overall index of the challenges of smart city development.

\section{Development of suitable weightings for the dimensions and their sub-attributes}

To determine the principal challenges of smart cities development using FSE, suitable weightings for the main six dimensions and 34 sub-attributes were first determined using equation 1. Table 2 shows that the mean ratings and weightings of the challenges of smart city development in Nigeria. 


$$
W_{i}=\frac{M_{j}}{\sum_{i=1}^{5} M_{j}}
$$

Where:

$W_{i}$ is the weightings of each dimension or sub-attributes

$M_{j}$ is the mean rating of each dimension or sub-attributes

$\sum M_{j}$ is the summation of mean ratings of all dimensions or sub-attributes

For example, EC1 has a mean score of 3.73 while the total mean for the economic dimension is 13.12. The weighting for EC1 is therefore derived using equation 2:

$$
W_{E C 1}=\frac{3.73}{3.73+2.73+3.94+2.72}=\frac{3.73}{13.12}=0.28
$$

The weight for all other challenges can be calculated using the same procedure as above. Similarly, the total weight for each dimension can be derived by using the same approach. For example, the total mean for the economic dimension is 13.12 ; the total weight can be calculated using equation 3:

$$
W_{E c o} \frac{13.12}{13.12+28.77+25.42+16.57+20.77+14.01}=\frac{13.12}{118.66}=0.11
$$

<Insert Table 2 about here>

\section{Determination of membership functions for each dimension and their sub-attributes}

Based on the three basic elements of the FSE as noted by Xu et al. (2010), the basic factors can be written as $f=\left\{f_{1}, f_{2}, f_{3}, \ldots, \ldots, \ldots, f_{34}\right\}$, while the grading alternatives are $E=$ $\{1,2,3,4,5\}$ following the Likert scale adopted. The membership function of each factor can be computed, as seen in equation 4. For example, taking the first factor under the economic dimension (economic instability, EC1), the percentage response shows that while $2 \%$ of the respondents believe this factor has very low significance, $19 \%$ noted that it has low significance. However, $10 \%, 41 \%$ and $28 \%$ all noted that the level of significance of this factor is on the average, high and very high respectively. Thus, the membership function of this factor can be given as:

$$
E C 1=\frac{0.02}{\text { Very low }}+\frac{0.19}{\text { Low }}+\frac{0.10}{\text { Average }}+\frac{0.41}{\text { High }}+\frac{0.28}{\text { Very high }}=\frac{0.02}{1}+\frac{0.19}{2}+\frac{0.10}{3}+\frac{0.41}{4}+\frac{0.28}{5}
$$


The membership function for this factor can be expressed as $(0.02,0.19,0.10,0.41,0.28)$. Using this same approach, the membership function for all other factors can be computed, as seen in Table 3.

<Insert Table 3 about here>

\section{Fuzzy synthetic evaluation for the challenges of smart city development}

Following the evaluation of the challenges of smart city development (level 3) and the determination of the criticality of these dimensions (level 2), the next step was to determine the model that best explains the challenges facing city smartness. To achieve this, the four different model approach in the fuzzy environment were explored (cf. Xu et al., 2010; Chan et al., 2011) viz:

Model 1: $M(\wedge, \vee), b j=\vee_{i=1}^{m}(w i \wedge r i j) \quad \forall b j \in B$

Model 2: $M(\cdot, \mathrm{v}), b j=\bigvee_{i=1}^{m}(w i \times r i j) \quad \forall b j \in B$

Model 3: $M(\cdot, \oplus), \quad b j=\min \left(1, \sum_{i=1}^{m} w i \times r i j\right) \quad \forall b j \in B$

Model 4: $M(\wedge,+), b j=\sum_{i=1}^{m}(w i \wedge r i j) \quad \forall b j \in B$

While these four models have their unique characteristics, only model 3 is most suitable for this study as it can be adopted when many factors are being considered, and the difference in their weight is minimal (refer to Table 2). Models 1 and 2 are only suitable for problems that have single items as only the major criteria are considered, while model 4 has the tendency to ignore factors with very small weightings. Because numerous factors are assessed in this study (34) and they can be grouped into six major criteria, model 3 offers the most suitable solution in explaining the challenges facing city smartness in Nigeria.

$M(\cdot, \oplus), \quad b j=\min \left(1, \sum_{i=1}^{m} w i \times r i j\right) \quad \forall b j \in B$

Where $w_{i}=$ the weighting of a factor affecting smart city attainment $\mathrm{r}_{\mathrm{ij}}=$ the membership function of a factor affecting smart city attainment $\bigoplus=$ the sum of the product of weighting and membership function Thus, level 1, which is the overall index of the challenges of smart city development, is attained by:

$(0.11 \times 0.07+0.24 \times 0.03+0.21 \times 0.05+0.14 \times 0.07+0.18 \times 0.06+0.12 \times 0.04$,

$0.11 \times 0.23+0.24 \times 0.20+0.21 \times 0.18+0.14 \times 0.22+0.18 \times 0.28+0.12 \times 0.24$, 


$$
\begin{gathered}
0.11 \times 0.20+0.24 \times 0.216+0.21 \times 0.14+0.14 \times 0.15+0.18 \times 0.21+0.12 \times 0.13 \\
0.11 \times 0.30+0.24 \times 0.32+0.21 \times 0.29+0.14 \times 0.26+0.18 \times 0.32+0.12 \times 0.28, \\
0.11 \times 0.22+0.24 \times 0.29+0.21 \times 0.34+0.14 \times 0.26+0.18 \times 0.27+0.12 \times 0.31)=
\end{gathered}
$$

Membership function for all challenges of smart city development (Level 1) $=(0.050 .22$, $0.16,0.30,0.29)$.

Based on the values derived on level 1, the overall impact of the identified challenges on the attainment of city smartness can be derived using equation 5 .

$\mathrm{OIL}=\sum_{k=1}^{5}\left(W \times R_{k}\right) \times L$

Where;

$O I L=$ Overall impact level

$W=$ the weighting of each factor assessed

$R=$ the degree of membership function of each factor assessed

$L=$ is the linguistic variable (1=Very low, 2=Low, 3=Average, 4=High, 5=Very High)

Therefore OIL $=0.05 \times 1+0.22 \times 2+0.16 \times 3+0.30 \times 4+0.29 \times 5=\mathbf{3 . 6 2}$

Similarly, for each of the main dimensions, the overall impact is calculated using the above process, thus giving the impact levels in Figure 1. Considering the Likert scale of one to five with three being average, the $O I L$ of 3.62 derived implies that all the assessed 34 variables have a high impact on the attainment of a smart city in Nigeria as this is above average of 3.0. However, on an individual basis, variables relating to the environment have a higher significance level with an overall level of 3.87. This is followed by technology, social and legal-related variables with an impact level of 3.71, 3.64 and 3.57 respectively. Despite being the dimensions with the least impact level, the economic and political/governance dimensions still have impact level of above average. Figure 1 presents significant variables from these different dimensions. These variables were selected based on their average impact of 3.0 and above (refer to Table 2).

$<$ Insert Figure 1 about here> 


\section{Discussion of findings}

The study's findings revealed that the attainment of a smart city in Nigeria depends mostly on the government and stakeholders' ability to overcome critical challenges in the six different dimensions assessed. Although Rana et al. (2019) discovered that the critical issues facing smart city development is mostly governance related, the situation is slightly different in Nigeria. Despite governance having a significant impact, it was observed that the major challenge facing smart city development in Nigeria lies in the environment. More significantly, the issue of rapid urbanisation emanating from the continuous rise in population. At present, Nigeria has the highest population in Africa, with over 196 million people (United Nations, 2019). The resultant effect of this is the severe pressure on scarce resources and high urban migration in search of green pastures.

Furthermore, the study found that the epileptic internet connectivity in Nigeria and the lack of embrace of digital technologies are critical technological issues facing smart city development in the country. With the internet being the backbone of any connected city (Silva et al., 2018) a failure in the availability of functional connectivity will impede smart city development. The research findings further stressed the negative influence of the slow adoption of technology on cities development that has been observed in previous studies (AlNuaimi et al., 2015; Bibri, 2019; Rana et al., 2019). Other crucial challenges discovered include lack of awareness and poverty that has characterised the country in recent times. Before, thinking about smarty city, the government must tackle issues surrounding the basic needs of its citizens. Reducing the number of people living in extreme poverty which unfortunately is currently high (Danaan, 2018) should be a priority.

The implication of these findings is that smart city development will continue to be more of a dream than a reality in Nigeria unless policymakers find a way to checkmate the issue of high rate of urbanisation and increased population through proper development of rural areas. The government must also strive to improve basic infrastructure delivery, especially in the area of power supply which, according to Fabiyi et al. (2016), keeps deteriorating daily. There is the need to encourage and support internet service providers and ICT developers in a bid to encourage increased and efficient use of these facilities. Sensitisation of the public in terms of the need to actively participate in the attainment of smart city development and to imbibe the culture of proper maintenance of public infrastructure is equally important. With that being said, there is a high possibility of citizen's corporation not being achieved if the government 
fails to provide necessities such as a better education system, improved security from both cybercrime and terrorism and improved job opportunities. The government can equally champion the case of smart cities by creating policies and legislations that will support city smartness in the country.

\section{CONCLUSIONS}

The study's findings contribute to the body of knowledge as it illuminates the significant challenges of smart city development in Nigeria; a country that has gained less attention in the prevailing smart city discourse. Theoretically, the work creates a strong theoretical foundation for future studies on the attainment of a smart city in developing countries, particularly in Africa where the situations are similar to those observed in the current study area. Practically, the study's findings revealed that the country has more urgent issues to tackle before considering city transformation. These issues include high urbanisation, increased population growth, poor basic infrastructure, poverty, poor legislation and regulations, economic instability, poor governance etc. Thus, the findings afford practical insight to government and other stakeholders saddled with the responsibility for city development and the issues to be tackled. This is important if policy makers are to deliver social equality for their citizens.

While this study highlights significant insights into the challenges of smart city development, the findings were limited by certain factors. Most significant is the method adopted. Future studies can benefit from a mixed-method approach by first employing a Delphi method to validate the challenges gathered from literature before employing other quantitative methods of assessment. This will help bring a more subjective view of the challenges of smart city development. 


\section{REFERENCES}

Abigo, A., Madgwick, D., Gidado, K. and Okonji, S. (2012), "Embedding sustainable facilities management in the management of public buildings in Nigeria", Proceeding of Third International Conference on Engineering, Project and Production Management, University of Brighton, Brighton, September 10-11. Available at: https://cris.brighton.ac.uk/ws/portalfiles/portal/289785/Sustainable+Facilities+Manageme nt+in+public+buildings+in+Nigeria.pdf [accessed 23 August 2020]

Abioye, O. (2017), "Economy bleeds as CBN pursues elusive naira stability", Punch Newspaper, 29 May, Available at: http://punchng.com/economy-bleeds-as-cbn-pursueselusive-naira-stability/ [accessed 23 November, 2019]

Adefeso H.A and Mobolaji H.I (2010) "The Fiscal-Monetary Policy and Economic Growth in Nigeria", Further Empirical Evidence. Pakistan Journal of Social Sciences, Vol.7 No.2, pp. 137-142. DOI: https://doi.org/10.3923/pjssci.2010.137.142

Adepetun, A. (2017). "How Nigeria's slow Internet speed affects economic growth". The Guardian Newspaper. Available at: https://guardian.ng/business-services/how-nigeriasslow-internet-speed-affects-economic-growth/ [accessed 23 November, 2019]

Aghimien, D. O, Aghimien, E. I., Fadiyimu, A. O. and Adegbemo, T. F. (2018), "Survival Strategies for Construction Related Organisations in a Challenging Economy". Engineering, Construction and Architectural Management, Vol.25 No.7, pp. 861-876 DOI: https://doi.org/10.1108/ECAM-06-2017-0106

Aghimien, D. O, Aigbavboa, C.O., and Oke, A.E., (2019), "Viewing digitalisation in construction through the lens of past studies", Advances in ICT in Design, Construction and Management in Architecture, Engineering, Construction and Operations (AECO), Proceedings of the 36th CIB W78 2019 Conference, Northumbria University at Newcastle, United Kingdom, 18-20 September, pp.84-93

Akanni, K.A. and Osinowo, O.H. (2013), "Effect of Fiscal Instability on Economic Growth in Nigeria", Advances in Economics and Business, Vol.1 No.2, pp. 124-133 DOI: https://doi.org/10.13189/aeb.2013.010207

Alizadeh, T. (2017), “An investigation of IBM's Smarter Cites Challenge: What do participating cities want?" Cities, Vol.63, pp. 70-80. DOI: $\underline{\text { https://doi.org/10.1016/j.cities.2016.12.009 }}$ 
Al-Nuaimi, E., Al-Neyadi, H., Mohamed, H., and Al-Jaroodi, J. (2015), “Applications of big data to smart cities", Journal of Internet Services and Applications, Vol.6 No.25, pp. 625. DOI: https://doi.org/10.1186/s13174-015-0041-5

Al-Saeed, Y., Edwards, D. and Scaysbrook, S. (2020), "Automating construction manufacturing procedures using BIM digital objects (BDOs): Case study of knowledge transfer partnership project in UK", Construction Innovation, Vol. ahead-of-print No. ahead-of-print. DOI: https://doi.org/10.1108/CI-12-2019-0141

Ameyaw, E.E. and Chan, A.P.C. (2015), "Evaluation and ranking of risk factors in publicprivate partnership water supply projects in developing countries using fuzzy synthetic evaluation approach". Expert Systems with Applications, Vol.42 No.12, pp. 5102-5116. DOI: $\underline{\text { https://doi.org/10.1016/j.eswa.2015.02.041 }}$

Angelidou, M. (2014), "Smart city policies: A spatial approach”, Cities, Vol.41, pp.3-11. DOI: https://doi.org/10.1016/j.cities.2014.06.007

Atkinson, R. and Flint, J. (2001), “Accessing hidden and hard-to-reach populations: snowball research strategies", Social Research Update, Vol. 33, University of Surrey, Guildford, pp. 1-4. Available at: https://sru.soc.surrey.ac.uk/SRU33.html [accessed 23 ${ }^{\text {rd }}$ August 2020]

Bawa, M., Caganova, D., Szilva, I., and Spirkova, D. (2016), "Importance of Internet of Things and Big Data in Building Smart City and What Would Be Its Challenges”, A. Leon-Garcia et al. (Eds.): Smart City 2015, pp. 605-616. DOI: https://doi.org/10.1007/978-3-319-33681-7_52

Bello-Schünemann, J. and Porter, A. (2017), "Building the future Infrastructure in Nigeria until 2040”, West Africa Report 21 | November, Institute for Security Studies, pp.1-27. Available via: https://issafrica.s3.amazonaws.com/site/uploads/war-21.pdf [accessed 23rd August 2020]

Bibri, S.E. (2019), "On the sustainability of smart and smarter cities in the era of big data: an interdisciplinary and transdisciplinary literature review", Journal of Big Data, Vol.6 No.25, pp. 1-64. DOI: https://doi.org/10.1186/s40537-019-0182-7

Biswas, A. (2019), "Why Indian cities are so chaotic? Decoding from the urban development efforts of Chandigarh", Smart and Sustainable Built Environment, Vol. 8 No. 5, pp. 438456. https://doi.org/10.1108/SASBE-05-2018-0023

Blaxter, L., Huges, C. and Tight,M. (2001), "How to Research", 2nd ed., Open University Press, London. ISBN-13: 978-0335238675 
Chan, A.P.C., Darko, A. and Ameyaw, E.E. (2017), "Strategies for promoting green building technologies adoption in the construction industry - an international study", Sustainability, Vol. 9 No. 6, pp. 1-18. DOI: https://doi.org/10.3390/su9060969

Chan, J.H.L., D.W.M. Chan, A.P.C. Chan, P.T.I. Lam and Yeung, J.F.Y. (2011), "Developing a fuzzy risk assessment model for guaranteed maximum price and target cost contracts in construction". Journal of Facilities Management, Vol.9 No.1, pp. 34-51. DOI: https://doi.org/10.1108/F-08-2012-0063

Chourabi, H., Nam, T.,Walker, S., Gil-Garcia, J. R.,Mellouli, S., Nahon, K., Pardo, T. A. and Scholl, H. J. (2012), "Understanding smart cities: An integrative framework". 45th Hawaii international conference on system science, pp. 2289-2297. DOI: https://doi.org/10.1109/HICSS.2012.615

Clarke, N.J., Kuipers, M.C. and Roos, J. (2019), "Cultural resilience and the Smart and Sustainable City: Exploring changing concepts on built heritage and urban redevelopment", Smart and Sustainable Built Environment, Vol. 9 No. 2, pp. 144-155. https://doi.org/10.1108/SASBE-09-2017-0041

Cowen, T. (2014), “China's megacities: No two cities are the same”, Gulf News Thinkers. Available on: https://gulfnews.com/opinion/thinkers/china-s-megacities-no-two-citiesare-the-same-1.2080002 [accessed 19 June, 2020]

Crnjac, M., Veža, I., and Banduka, N. (2017), "From Concept to the Introduction of Industry 4.0". International Journal of Industrial Engineering and Management, Vol.8 No.1, pp. 21-30. DOI: https://bib.irb.hr/datoteka/894382.IJIEM_24.pdf

Danaan, V. (2018), “Analysing Poverty in Nigeria through Theoretical Lenses”, Journal of Sustainable Development, Vol.11No.1, pp. 20-31. DOI. https://doi.org/10.5539/jsd.v11n1p20

Datta, A. (2015), "New urban utopias of postcolonial India: 'entrepreneurial urbanisation in Dholera smart city, Gujarat". Dialogue Hum. Geogr. Vol.5 No.1, pp. 3-22. DOI: https://doi.org/10.1177/2043820614565748

Edwards, D. J., Pärn, E. A., Sing, C. P. and Thwala, W.D. (2019) Risk of excavators overturning: determining horizontal centrifugal force when slewing freely suspended loads. Engineering, Construction and Architectural Management. 26(3), pp. 479-498. DOI: https://doi.org/10.1108/ECAM-03-2018-0125

Edwards, D.J., Rillie, I., Chileshe, N. Lai, J., Hossieni , M. Reza, and Thwala, W.D. (2020) A field survey of hand-arm vibration exposure in the UK utilities sector, Engineering, 
Construction and Architectural Management. DOI: https://doi.org/10.1108/ECAM-092019-0518

Ekwealor, V. (2016), "The challenges to Lagos becoming a Smart City", Techpoint, Available on https://techpoint.ng/author/suave/ [accessed 19 June, 2020]

Erol, S., Jäger, A., Hold, P., Ott, K., and Sihn, W. (2016). “Tangible Industry 4.0: a scenariobased approach to learning for the future of production", Procedia CIRP 54, pp.13 18.DOI: https://doi.org/10.1016/j.procir.2016.03.162

Fabiyi, S.D., Abdulmalik, A.O., Tiamiu, H.A. (2016), "Dwindling Electrical Power Supply in Nigeria: Causes and Possible Solutions", International Journal of Science and Research, Vol.5 No.5, pp. 635-639. DOI: https://doi.org/10.21275/v5i5.nov163290

George, I.N. and Ukpong, D. E. (2013), "Contemporary Social Problems in Nigeria and its Impact on National Development: Implication for Guidance and Counselling Services”, Journal of Educational and Social Research, Vol.3 No.2, pp. 167-173 DOI: https://doi.org/10.5901/jesr.2013.v3n2p167

Ghasemi, A. and Zahedias1, S. (2012), "Normality test for statistical analysis: a guide for non-statisticians", International Journal of Endocrinology and Metabolism, Vol. 10 No. 2, pp. 486-489. DOI: https://doi.org/10.5812/ijem.3505

Ghosh, A., Edwards, D.J., Hossieni, M. Reza., Al-Ameri, R., Abewajy, J. and Thwala, W.D. (2020), "Real-Time Structural Health Monitoring for Concrete Beams: A Cost-Effective 'Industry 4.0' Solution Using Piezo Sensors", International Journal of Building Pathology and Adaptation. Vol. ahead-of-print No. ahead-of-print. DOI: https://doi.org/10.1108/IJBPA-12-2019-0111

Giffinger, R., Haindlmaier, G., and Kramar, H. (2010), “The role of rankings in growing city competition", Urban Research and Practice, Vol. 3, pp. 299-312. DOI: https://doi.org/10.1080/17535069.2010.524420

Heckathorn, D.D. (2011), "Comments: Snowballing versus respondent-driven sampling”, Sociological Methodology, Vol. 41 No. 1, pp. 355-366. DOI: https://doi.org/10.1111/j.1467-9531.2011.01244.x

Hollands, R. G. (2008). "Will the real smart city please stand up?" City: Analysis of urban trends, culture, theory, policy, action, 12(3), 303-320, 2008. DOI: https://doi.org/10.1080/13604810802479126

Khan, M, Uddin MF, and Gupta N. (2014), “Seven V's of Big Data understanding Big Data to extract value", In American Society for Engineering Education, Zone 1 Conference of the IEEE; pp. 1-5. DOI: https://doi.org/10.1109/ASEEZone1.2014.6820689 
Kogan, N. and Lee, K.J. (2014), "Exploratory research on success factors and challenges of smart city projects", MSc Thesis, Kyung Hee University, Seoul, South Korea. DOI: https://doi.org/10.14329/APJIS.2014.24.2.141

Komolafe, M.O., Oyewole, M.O. and Gbadegesin, J.T. (2019), "Stakeholders' relevance in sustainable residential property development", Smart and Sustainable Built Environment, Vol. 9 No. 2, pp. 112-129. https://doi.org/10.1108/SASBE-07-2019-0094

Koppenjan, J. F., and Enserink, B. (2009), "Public-private partnerships in urban infrastructures: Reconciling private sector participation and sustainability", Public Administration Review, Vol.69 No.2, pp. 284-296. DOI: https://doi.org/10.1111/j.1540$\underline{6210.2008 .01974 . x}$

Kramers, A, Höjer M, Lövehagen N, Wangel J. (2014), "Smart sustainable cities-Exploring ICT solutions for reduced energy use in cities”, Environ Model Software, Vol. 56, pp. 5262. DOI: https://doi.org/10.1016/j.envsoft.2013.12.019

Kumar, T.M.V. and Dahiya, B. (2017), "Smart Economy in Smart Cities", In T.M. Vinod Kumar (ed.), Advances in 21st Century Human Settlements, 1-76. DOI: https://doi.org/10.1007/978-981-10-1610-3_1

Kummitha, R.K.R and Crutzen, N. (2019), "Smart cities and the citizen-driven internet of things: A qualitative inquiry into an emerging smart city", Technological Forecasting and Social Change, Vol.140, pp.44-53. DOI: https://doi.org/10.1016/j.techfore.2018.12.001

Loghin, D., Chen, C.G. Dinh, T.T.A., Fan, F., Lin, Q., Ng, J., Ooi, C., Sun, X., Ta, Q., Wang, W., Xiao, X., Yang, Y., Zhang, M., and Zhang, Z. (2020). "The Disruptions of 5G on Data-driven Technologies and Applications" IEEE transactions on knowledge and data $\begin{array}{llllll}\text { engineering, } & \text { Vol. } & \text { 32, } & \text { No. } & \text { p. 1179-1198. } & \text { DOI: }\end{array}$ https://doi.org/10.1109/TKDE.2020.2967670

Ma, J., Kremer, G.E.O. (2015), “A fuzzy logic-based approach to determine product component end-of-life option from the views of sustainability and designer's perception", J. Clean. Prod. Vol.108, pp.289-300. DOI: https://doi.org/10.1016/j.jclepro.2015.08.029

Marabissi, D., Mucchi, L., Fantacci, R., Spada, M.R., Massimiani, F., Fratini, A., Cau, G., Yunpeng, J., and Fedele, L. (2019). "A Real Case of Implementation of the Future 5G City", Future internet, Vol.11 No. 4 pp.1-16 DOI: https://doi.org/10.3390/fi11010004

Monzon, A. (2015), "Smart cities concept and challenges: Bases for the assessment of smart city projects", International conference on smart cities and green ICT systems, pp.17-31.

Moser, C.A. and Kalton, G. (1999), "Survey Methods in Social Investigation", 2nd Edition, Gower Publishing Company, Aldershot. ASIN/ISBN: B0006BXIP2 
Mu, S., Cheng, H., Chohr, M., Peng, W. (2014), “Assessing risk management capability of contractors in subway projects in mainland China”. Int. J. Proj. Manag. Vol.32 No.3, pp. 452-460.DOI: https://doi.org/10.1016/j.ijproman.2013.08.007

Nam, T., and Pardo, T. (2011). Smart city as urban innovation: Focusing on management, policy, and context. University of Albany. Available at: https://www.ctg.albany.edu/media/pubs/pdfs/icegov_2011_smartcity.pdf [accessed 19 June, 2020]

Neirotti, P., De Marco, A., Cagliano, A. C., Mangano, G., and Scorrano, F. (2014), "Current trends in smart city initiatives: Some stylised facts”. Cities, Vol.38, pp.25-36. DOI: https://doi.org/10.1016/j.cities.2013.12.010

Newman, C., Edwards, D.J., Martek, I., Lai, J. and Thwala, W.D. (2020), "Industry 4.0 Deployment in the Construction Industry: A Bibliometric Literature Review and UKbased Case Study", Smart and Sustainable Built Environment DOI: https://doi.org/10.1108/SASBE-02-2020-0016

Ogundare, B. A., and Ogunbodede, E. F. (2014), “Traffic Congestion and Parking Difficulties in Akure Metropolis, Nigeria", IOSR Journal of Humanities and Social Science, Vol.19 No.8, pp. 1-7. DOI: https://doi.org/10.9790/0837-19820107

Oladapo, A. A. (2007), “An investigation into the use of ICT in the Nigerian construction industry”. Journal of Information Technology in Construction, Vol. 12, pp. 261-277. DOI: https://www.itcon.org/papers/2007_18.content.02391.pdf

Olugboyega, O., Windapo, A., Omopariola, A.D., Edwards, D.J. and Martek, I. (2020) Development of a conceptual model for evaluating the success of BIM-based construction projects, Smart and Sustainable Built Environment. DOI: https://doi.org/10.1108/SASBE$\underline{02-2020-0013}$

Pärn, E. A. and Edwards, D. J. (2019), "Cyber threats confronting the digital built environment: Common data environment vulnerabilities and block chain deterrence", Engineering, Construction and Architectural Management, Vol. 26 No. 2, pp. 245-266. DOI: https://doi.org/10.1108/ECAM-03-2018-0101

Pedrycz, W., Ekel, P., Parreiras, R. (2011), “Fuzzy Multicriteria Decision-making: Models, Methods and Applications", John Wiley and Sons, Chichester, England. ISBN: 978-0470-68225-8

Rahman, M., (2014), “Barriers of implementing modern methods of construction”, Journal of Management in Engineering, Vol. 30 No. 1, pp. 69-77 DOI: https://doi.org/10.1061/(ASCE)ME.1943-5479.0000173 
Rana, N.P., Luthra, S., Kumar, S., Mangla, S.K., Islam, R., Roderick, S., and Dwivedi, Y.K (2019), "Barriers to the Development of Smart Cities in Indian Context", Information Systems Frontiers, Vol. 21, pp. 503-525 DOI: https://doi.org/10.1007/s10796-018-9873-4

Roberts, C. J., Pärn, E. A., Edwards, D. J. and Aigbavboa, C. (2018) Digitalising asset management: concomitant benefits and persistent challenges. International Journal of Building Pathology and Adaptation, Vol. 36, No. 2, pp. 152-173. DOI:10.1108/IJBPA09-2017-0036

Ruhlandt, R.W.S., (2018), “The governance of smart cities: A systematic literature review”, Cities, Vol.81, pp. 1-23 DOI: https://doi.org/10.1016/j.cities.2018.02.014

Scuotto, V., Ferraris, A., and Bresciani, S. (2016), "Internet of things: Applications and challenges in smart cities: A case study of IBM smart city projects”. Business Process Management Journal, Vol.22 No.2, pp. 357-367. DOI: https://doi.org/10.1108/BPMJ-052015-0074

Sepasgozar, S.M.E., Hawken, S., Sargolzaei, S., Foroozanfa, M. (2019), "Implementing citizen centric technology in developing smart cities: A model for predicting the acceptance of urban technologies", Technological Forecasting and Social Change, Vol.142, pp.105-116 DOI: https://doi.org/10.1016/j.techfore.2018.09.012

Sikora-Fernandez, D. (2018), "Smarter Cities in Post-Socialist Country: Example of Poland, Cities, 78, pp. 52-59 DOI: https://doi.org/10.1016/j.cities.2018.03.011

Silva, B. N., Khan, M., and Han, K. (2018), "Towards Sustainable Smart Cities: A Review of Trends, Architectures, Components, and Open Challenges in Smart Cities", Sustainable Cities and Society, Vol.38, pp.697-713. DOI: https://doi.org/10.1016/j.scs.2018.01.053

Tan, W.C.K. (2011), "Practical Research Methods", Pearson Custom, Singapore. ISBN-13: 978-9810680213

United Nations (2017), "Drivers of Migration and Urbanisation in Africa - Key trends and Issues". United Nations Expert Group Meeting on Sustainable Cities, Human Mobility and International Migration, New York, 7-8 September. Available via: https://www.un.org/en/development/desa/population/events/pdf/expert/27/papers/III/pape r-Awunbila-final.pdf [accessed 23rd August 2020]

United Nations, Department of Economic and Social Affairs (2019). World population prospect $2019 . \quad$ Available at: https://population.un.org/wpp/Publications/Files/WPP2019_Highlights.pdf [accessed 19th June, 2020] 
Vanguard, (2018), "Nigeria overtakes India as world's poverty capital — Report". June 25, 2018. Available on: https://www.vanguardngr.com/2018/06/nigeria-overtakes-india-asworlds-poverty-capital-report/ [accessed 19 June, 2020]

Wong, J.K.W., Chan, J.K.S. and Wadu, M.J. (2016), "Facilitating effective green procurement in construction projects: an empirical study of the enablers", Journal of Cleaner Production, Vol. 135, pp. 859-871 DOI: https://doi.org/10.1016/j.jclepro.2016.07.001

Wuni, I.Y., Shen, G.Q., Osei-Kyei, R., and Agyeman-Yeboah, S. (2020). "Modelling the critical risk factors for modular integrated construction projects", International Journal of Construction Management, Early cite. DOI: https://doi.org/10.1080/15623599.2020.1763049

Xia, B., Chan, A.P.C., Yeung, J.F.Y. (2011), "Developing a fuzzy multicriteria decisionmaking model for selecting design-build operational variations", J. Constr. Eng. Manag. Vol.137 No.12, pp. 1176-1184. DOI: https://doi.org/10.1061/(ASCE)CO.1943$\underline{7862.0000381}$

Xu, Y., Chan, A.P.C., Yeung, J.F.Y., Chan, D.W.M., Wang, S. and Ke, Y. (2010). Developing a risk assessment model for PPP projects in China: a fuzzy synthetic evaluation approach. Automation in Construction, Vol.19 No.7, pp. 929-943 DOI: https://doi.org/10.1016/j.autcon.2010.06.006

Yang, K., and Callahan, K. (2007), "Citizen involvement efforts and bureaucratic responsiveness: Participatory values, stakeholder pressures, and administrative practicality", Public Administration Review, Vol.67 No.2, pp. 249-264. DOI: https://doi.org/10.1111/j.1540-6210.2007.00711.x

Zhao, X., Hwang, B., and Gao, Y. (2016), “A fuzzy synthetic evaluation approach for risk assessment: a case of Singapore green projects". Journal of Cleaner Production, Vol.115, pp. 203 - 213 DOI: https://doi.org/10.1016/j.jclepro.2015.11.042

Zhao, X., Hwang, B.G., Low, S.P. (2013), "Developing fuzzy enterprise risk management maturity model for construction firms", J. Constr. Eng. Manag. Vol.139 No.9, pp. 11791189. DOI: https://doi.org/10.1061/(ASCE)CO.1943-7862.0000712

Zimmermann, H.J. (2001), "Fuzzy Set Theory and its Applications", fourth ed. Kluwer Academic Publishers, Boston, MA. DOI: https://doi.org/10.1007/978-94-010-0646-0 
Table 1 - Challenges of smart city development

\begin{tabular}{|c|c|}
\hline Challenges & Authors \\
\hline \multicolumn{2}{|l|}{ Economic } \\
\hline Economic instability (EC1) & Bello-Schünemann and Porter (2017); Monzon (2015) \\
\hline Absence of foreign investors (EC2) & Kumar and Dahiya (2017) \\
\hline High cost of IT training and skills development (EC3) & $\begin{array}{l}\text { Al-Nuaimi et al. (2015); Chourabi et al. (2012); Rana et al. } \\
\text { (2019) }\end{array}$ \\
\hline Lack of competitiveness among local firms (EC4) & Monzon (2015) \\
\hline \multicolumn{2}{|l|}{ Social } \\
\hline Poverty (S1) & Danaan (2018); Monzon (2015) \\
\hline Poor education (S2) & Monzon (2015) \\
\hline High rate of unemployment (S3) & Danaan (2018); Monzon (2015) \\
\hline Terrorism (S4) & Danaan (2018) \\
\hline Poor infrastructure maintenance culture (S5) & Abigo et al. (2012) \\
\hline Lack of citizen participation (S6) & $\begin{array}{l}\text { Datta (2015); Kogan and Lee (2014); Kummitha and Crutzen } \\
\text { (2019); Nam and Pardo (2011) }\end{array}$ \\
\hline $\begin{array}{l}\text { Lack of awareness of the concept of smart cities among } \\
\text { citizens (S7) }\end{array}$ & Kogan and Lee (2014) \\
\hline Fear of potential systems failure (S8) & Datta (2016) \\
\hline \multicolumn{2}{|l|}{ Technology } \\
\hline Cyber insecurity (T1) & $\begin{array}{l}\text { Al-Nuaimi et al. (2015); Bawa et al. (2016); Rana et al. } \\
\text { (2019) }\end{array}$ \\
\hline Poor utilisation of digital technologies (T2) & Bibri (2019); Olugboyega et al. (2020) \\
\hline Poor internet connectivity/provision (T3) & Adepetun (2017); Datta (2016) \\
\hline Absence of a common information system (IS) model (T4) & Chourabi et al. (2012); Monzon (2015) \\
\hline Lack of technological knowledge among city planners (T5) & Scuotto et al. (2016) \\
\hline $\begin{array}{l}\text { Lack of integration and convergence across IT networks } \\
\text { (T6) }\end{array}$ & Bawa et al. (2016); \\
\hline Poor information storage and data retrieval (T7) & Al-Nuaimi et al. (2015) \\
\hline \multicolumn{2}{|l|}{ Politics/Governance } \\
\hline $\begin{array}{l}\text { Lack of cooperation and coordination between city's } \\
\text { networks (PG1) }\end{array}$ & Kogan and Lee (2014); Nam and Pardo (2011); \\
\hline Epileptic power supply (PG2) & Oladapo (2007) \\
\hline Poor governance/lack of trust in government (PG3) & Ruhlandt (2018) \\
\hline Absence of public-private partnership participation (PG4) & Koppenjan and Enserink (2009) \\
\hline Political instability (PG4) & Kogan and Lee (2014); Monzon (2015) \\
\hline \multicolumn{2}{|l|}{ Environment } \\
\hline \multicolumn{2}{|l|}{ Poor planning of cities (EN1) } \\
\hline High rate of urbanisation (EN2) & Ogundare and Ogunbodede (2014) \\
\hline Increase in population rate (EN3) & $\begin{array}{l}\text { Al-Nuaimi et al. (2015); George and Ukpong (2013); Kramers } \\
\text { et al. (2014); Neirotti et al. (2014) }\end{array}$ \\
\hline Traffic congestions in cities (EN4) & Neirotti et al. (2014) \\
\hline Lack of sustainability consideration (EN5) & Bibri (2019); Neirotti et al. (2014); Rana et al. (2019) \\
\hline Poor waste management (EN6) & Neirotti et al. (2014); Rana et al. (2019) \\
\hline \multicolumn{2}{|l|}{ Legal } \\
\hline $\begin{array}{l}\text { Lack of regulatory norms, policies and directions for smart } \\
\text { city (L1) }\end{array}$ & Chourabi et al. (2012) \\
\hline Cultural diversity (L2) & Chourabi et al. (2012); Nam and Pardo (2011) \\
\hline Lack of standardisation (L3) & Bawa et al., (2016); Kogan and Lee (2014) \\
\hline Legal restrictions impeding easy access to data (L4) & $\begin{array}{l}\text { Al-Nuaimi et al. (2015); Khan et al. (2014); Kogan and Lee } \\
\text { (2014) }\end{array}$ \\
\hline
\end{tabular}


Table 2 - Kruskal-Wallis Test, mean ratings and weightings of the challenges of smart city development

\begin{tabular}{|c|c|c|c|c|c|c|c|}
\hline \multirow[b]{2}{*}{ Dimensions } & \multirow[b]{2}{*}{$\begin{array}{l}\text { Sub- } \\
\text { attributes }\end{array}$} & \multicolumn{2}{|c|}{ Kruskal-Wallis } & \multirow[b]{2}{*}{$\begin{array}{l}\text { Mean } \\
\text { score }\end{array}$} & \multirow[b]{2}{*}{ Weighting } & \multirow[b]{2}{*}{$\begin{array}{l}\text { Total mean for } \\
\text { each dimension }\end{array}$} & \multirow[b]{2}{*}{$\begin{array}{l}\text { Total weighting } \\
\text { for each } \\
\text { dimension }\end{array}$} \\
\hline & & Chi-Sq. & Sig. & & & & \\
\hline \multirow{3}{*}{ Economic } & $\mathrm{EC} 2$ & 8.465 & 0.132 & 2.73 & 0.21 & \multirow{3}{*}{13.12} & \multirow{3}{*}{0.11} \\
\hline & EC3 & 9.709 & 0.084 & 3.94 & 0.30 & & \\
\hline & $\mathrm{EC} 4$ & 2.621 & 0.758 & 2.72 & 0.21 & & \\
\hline \multirow{6}{*}{ Social } & $\mathrm{S} 2$ & 6.608 & 0.251 & 3.42 & 0.12 & \multirow{6}{*}{28.77} & \multirow{6}{*}{0.24} \\
\hline & S3 & 3.773 & 0.583 & 3.16 & 0.11 & & \\
\hline & $\mathrm{S} 4$ & 6.432 & 0.266 & 3.39 & 0.12 & & \\
\hline & S5 & 2.887 & 0.717 & 3.79 & 0.13 & & \\
\hline & S6 & 4.116 & 0.533 & 3.60 & 0.13 & & \\
\hline & S7 & 2.229 & 0.817 & 4.38 & 0.15 & & \\
\hline \multirow{4}{*}{ Technology } & $\mathrm{T} 4$ & 4.189 & 0.523 & 2.95 & 0.12 & \multirow{4}{*}{25.42} & \multirow{4}{*}{0.21} \\
\hline & T5 & 3.874 & 0.568 & 3.60 & 0.14 & & \\
\hline & T6 & 3.908 & 0.563 & 2.88 & 0.11 & & \\
\hline & $\mathrm{T} 7$ & 8.885 & 0.114 & 3.85 & 0.15 & & \\
\hline \multirow[t]{5}{*}{ Politics/Governance } & PG1 & 10.469 & 0.063 & 2.85 & 0.14 & \multirow[t]{5}{*}{16.57} & \multirow[t]{5}{*}{0.14} \\
\hline & PG2 & 15.902 & $0.007 * *$ & 3.94 & 0.24 & & \\
\hline & PG3 & 3.067 & 0.690 & 4.03 & 0.24 & & \\
\hline & PG4 & 2.650 & 0.754 & 2.95 & 0.18 & & \\
\hline & PG4 & 6.628 & 0.250 & 2.81 & 0.17 & & \\
\hline \multirow[t]{2}{*}{ Environment } & EN1 & 10.146 & 0.071 & 3.06 & 0.15 & \multirow[t]{2}{*}{20.77} & \multirow[t]{2}{*}{0.18} \\
\hline & EN2 & 3.480 & 0.626 & 3.67 & 0.18 & & \\
\hline
\end{tabular}


Table 3 - Membership function of the challenges of smart city development

\begin{tabular}{|c|c|c|c|c|}
\hline Dimensions & Sub-attributes & Weighting & $\begin{array}{l}\text { Membership function level } 3 \\
\text { (sub-attributes) }\end{array}$ & $\begin{array}{l}\text { Membership function level } 2 \\
\text { (Dimensions) }\end{array}$ \\
\hline \multirow[t]{4}{*}{ Economic } & EC1 & 0.28 & $(0.02,0.19,0.10,0.41,0.28)$ & $(0.07,0.23,0.20,0.30,0.22)$ \\
\hline & EC2 & 0.21 & $(0.18,0.29,0.27,0.18,0.09)$ & \\
\hline & EC3 & 0.30 & $(0.01,0.14,0.12,0.36,0.37)$ & \\
\hline & EC4 & 0.21 & $(0.10,0.36,0.31,0.16,0.06)$ & \\
\hline \multirow[t]{8}{*}{ Social } & $\mathrm{S} 1$ & 0.13 & $(0.01,0.11,0.26,0.31,0.31)$ & $(0.03,0.20,0.16,0.32,0.29)$ \\
\hline & $\mathrm{S} 2$ & 0.12 & $(0.08,0.19,0.21,0.26,0.25)$ & \\
\hline & S3 & 0.11 & $(0.07,0.30,0.24,0.18,0.21)$ & \\
\hline & S4 & 0.12 & $(0.03,0.29,0.14,0.34,0.20)$ & \\
\hline & S5 & 0.13 & $(0.01,0.21,0.14,0.29,0.36)$ & \\
\hline & S6 & 0.13 & $(0.04,0.23,0.08,0.39,0.26)$ & \\
\hline & S7 & 0.15 & $(0.00,0.05,0.02,0.44,0.49)$ & \\
\hline & S8 & 0.11 & $(0.06,0.27,0.21,0.27,0.18)$ & \\
\hline \multirow[t]{7}{*}{ Technology } & $\mathrm{T} 1$ & 0.15 & $(0.03,0.14,0.14,0.32,0.37)$ & $(0.05,0.18,0.14,0.29,0.34)$ \\
\hline & $\mathrm{T} 2$ & 0.16 & $(0.00,0.14,0.11,0.33,0.42)$ & \\
\hline & $\mathrm{T} 3$ & 0.17 & $(0.00,0.08,0.10,0.34,0.49)$ & \\
\hline & $\mathrm{T} 4$ & 0.12 & $(0.08,0.38,0.21,0.18,0.16)$ & \\
\hline & $\mathrm{T} 5$ & 0.14 & $(0.10,0.18,0.07,0.34,0.32)$ & \\
\hline & T6 & 0.11 & $(0.12,0.29,0.27,0.20,0.11)$ & \\
\hline & $\mathrm{T} 7$ & 0.15 & $(0.05,0.16,0.12,0.27,0.42)$ & \\
\hline \multirow[t]{5}{*}{ Politics/Governance } & PG1 & 0.14 & $(0.10,0.34,0.27,0.16,0.12)$ & $(0.07,0.22,0.15,0.26,0.97)$ \\
\hline & PG2 & 0.24 & $(0.01,0.15,0.12,0.32,0.40)$ & \\
\hline & PG3 & 0.24 & $(0.07,0.08,0.05,0.35,0.45)$ & \\
\hline & PG4 & 0.18 & $(0.12,0.32,0.18,0.24,0.14)$ & \\
\hline & PG4 & 0.17 & $(0.08,0.39,0.25,0.19,0.09)$ & \\
\hline \multirow[t]{6}{*}{ Environment } & EN1 & 0.15 & $(0.11,0.25,0.27,0.21,0.16)$ & $(0.06,0.28,0.21,0.32,0.27)$ \\
\hline & EN2 & 0.18 & $(0.05,0.18,0.17,0.24,0.36)$ & \\
\hline & EN3 & 0.17 & $(0.03,0.23,0.12,0.40,0.23)$ & \\
\hline & EN4 & 0.16 & $(0.06,0.25,0.19,0.27,0.21)$ & \\
\hline & EN5 & 0.18 & $(0.01,0.21,0.14,0.39,0.25)$ & \\
\hline & EN6 & 0.17 & $(0.03,0.27,0.14,0.28,0.29)$ & \\
\hline \multirow[t]{4}{*}{ Legal } & L1 & 0.29 & $(0.00,0.14,0.10,0.36,0.40)$ & $(0.04,0.24,0.13,0.28,0.31)$ \\
\hline & $\mathrm{L} 2$ & 0.19 & $(0.14,0.40,0.21,0.10,0.14)$ & \\
\hline & L3 & 0.26 & $(0.02,0.24,0.12,0.32,0.30)$ & \\
\hline & L4 & 0.26 & $(0.05,0.22,0.12,0.27,0.34)$ & \\
\hline
\end{tabular}


Smart City Challenges

Overall impact level - 3.62

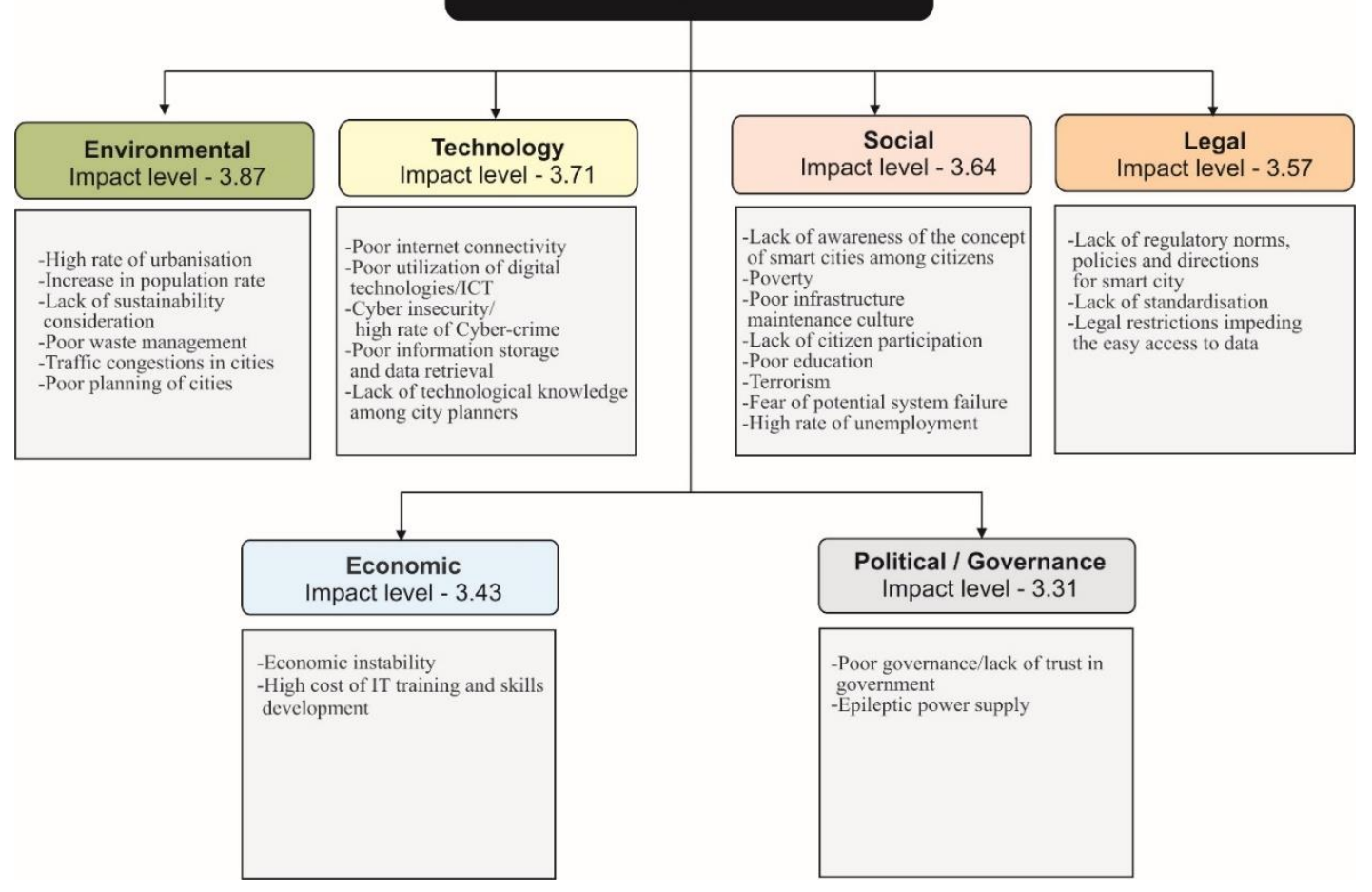

Figure 1 - Significant challenges of smart city attainment in Nigeria 